\title{
Articles
}

\section{Recruiting European Judges in the Age of Judicial Self- Government}

\author{
By Samuel Spáč
}

\begin{abstract}
Through the recruitment of judges - their selection and subsequent appointment powerful actors control who enters the judicial ranks and under what circumstances. In this paper I address how are European judges recruited using examples from ten European countries, while paying special attention to the role of the judicial self-government in these processes. Indeed, there are differences between recruitment processes across Europe. In some countries, a central role in the judicial recruitment is played by judicial schools; elsewhere crucial powers belong to judicial councils and/or other bodies of judicial selfgovernment; in the UK or Ireland some of these powers were vested in the hands of specialized bodies; whereas in other countries the process remains less formal with crucial powers resting in the hands of court presidents. Despite these differences, I choose to emphasize similarities recruitment processes share. They operate as funnels where the pool of candidates gradually decreases until only one (or few) remains and is eventually appointed. In order to assume judicial office one usually must (a) meet eligibility criteria, (b) get on selector's radar to be actively considered for the position, (c) get shortlisted for the position, (d) get selected, and (e) eventually appointed. Dividing the recruitment process into these stages, while paying attention to motivations of all involved actors, can help deepen our understanding of how judicial recruitment actually works and how formal and informal rules together shape the composition of judiciaries.
\end{abstract}

\footnotetext{
"Samuel Spáč is a senior researcher at the Judicial Studies Institute (JUSTIN), Masaryk University, and a researcher at the Department of Political Science, Cornelius University. Email: samuel.spac@law.muni.cz. I am grateful to Chris Hanretty for discussions that serve as a basis for the ideas presented in this paper, and for all the comments to participants of JUSTIN research meetings. The research leading to this article has received funding from the European Research Council (ERC) under the European Union's Horizon 2020 research and innovation programme (grant no. 678375-JUDI-ARCH-ERC-2015-STG).
} 


\section{A. Introduction}

Through the recruitment of judges - their selection and subsequent appointment powerful actors control who enters the judicial ranks and under what circumstances. A vast literature has been dedicated to this topic, mainly in common law countries, ${ }^{1}$ Constitutional courts around the world, ${ }^{2}$ or international courts. ${ }^{3}$ Scholarly attention ${ }^{4}$ paid to judicial recruitment in ordinary judiciaries has mainly focused on the procedures and formal bodies involved in the process. ${ }^{5}$ Nevertheless, the question of how the process actually translates into the composition of the judiciary certainly has consequences for the expertise and quality of the bench, ${ }^{6}$ while it also affects such issues as diversity and representativeness of the judiciary, which are important from the perspective of representative democracy. ${ }^{7}$ In addition, as recruitment establishes a link between the selector and the judge, it can be linked with the independence of individual judges as well as judiciaries in collective terms. ${ }^{8}$ Once the judges are appointed, their performance affects public attitudes towards judicial institutions, as well as political institutions in a broader

\footnotetext{
${ }^{1}$ E.g. Judith Resnik, Judicial Selection and Democratic Theory: Demand, Supply, and Life Tenure, 26 CARDOzO L.R. 597 (2015); Lee Epstein \& Jack Knight \& Olga Shevtsova, Comparing Judicial Selection Systems, 10 WILLIAM \& MARY 7 (2007); Kate Malleson, Rethinking the Merit Principle in Judicial Selection, 33 JOURNAL OF LAW \& SOCIETY 126 (2006); Jan Van Zyl Smit, The Appointment, Tenure And Removal of Judges under CommonWealth PRINCIPLES (2015); Debating JUdicial APPoINTMENTS IN THE AGE Of Diversity (Graham Gee \& Erika Rackley eds., 2018).

2 E.g. Charles Manga Fombad, Appointment of constitutional adjudicators in Africa: some perspectives on how different systems yield similar outcomes, 46 THE JOURNAL OF LEGAL PLURALISM AND UNOFFICIAL LAW 249 (2014); TOM Ginsburg, Judicial Review in NeW Democracies: Constitutional Courts in Asian Cases (2003); Rule by LaW: The Politics OF COURTS IN AUTHORITARIAN REgIMES (Tom Ginsburg \& Tamir Moustafa eds., 2008).
}

${ }^{3}$ Erik Voeten, The Politics of International Judicial Appointments: Evidence from the European Court of Human Rights, 61 International Organization 669 (2007); Michal Bobek, Selecting Europe's Judges: A CRitical ReVIEW OF the APPOINTMENT PROCEDURES TO THE EUROPEAN COURTS (OUP 2015).

${ }^{4}$ It needs to be admitted that in my research I am limited to the literature written in English, Slovak or Czech, hence there is a possibility that a considerable amount of research written in other languages is omitted.

${ }^{5}$ E.g. Carlo Guarnieri, Appointment and career of judges in continental Europe: the rise of judicial self-government, 24 Legal Studies 169 (2004); John Bell, Judiciaries Within Europe. A Comparative ReView (2006); Recruitment, Professional Evaluation and Career of Judges and Prosecutors in Europe (Giuseppe Di Federico ed., 2005); or some chapters in ApPointing JUdges IN AN Age Of JUdicial Power (Kate Malleson \& Peter H. Russell eds., 2006).

${ }^{6}$ E.g. Michael R. Dimino, The Futile Quest for a System of Judicial "Merit" Selection, 67 ALbany L.R. 803 (2004).

${ }^{7}$ E.g. Bell, supra note 5, regularly addresses the representation of women; Malleson, supra note 1; Kate Malleson, The Disruptive Potential of Ceiling Quotas in Addressing the Over-Representation in the Judiciary, in DeBATING JUDICIAL APPOINTMENTS IN THE AGE OF DIVERSITY 259 (Graham Gee \& Erika Rackley eds., 2018); Erika Rackley, Women, Judging and the judiciary: from difference to diversity (2013); and even CEPEJ reports address the share of women in European judiciaries, see for instance: Council of Europe, European Commission for the Efficiency of Justice, European judicial systems: Efficiency and quality of justice 97-101 (2016).

${ }^{8}$ Charles G. Geyh, The Endless Judicial Selection Debate and Why It Matters for Judicial Independence, 21 THE GEORGETOWN JOURNAL OF LEGAL ETHICS 1259 (2008). 
sense, $^{9}$ the state of the rule of law, ${ }^{10}$ and can be even connected to economic performance. $^{11}$

Over the last couple of decades, the world has observed an undeniable increase of judicial power and a growing involvement of judges in the administration of judiciaries. ${ }^{12}$ Judicial recruitment was one of the central issues in the debates surrounding it. In Europe, these changes were supported and encouraged by a variety of international documents, mainly backed by the European Commission and the Council of Europe. ${ }^{13}$ As early as in the 1980s, the ECtHR case law developed criteria for the assessment of independence of a tribunal; the manner through which members of such a body are appointed was one of them. ${ }^{14}$ Judgments remained rather vague as to what a proper mechanism is for appointment that would meet these criteria, therefore a variety of 'soft law' documents provided more guidance in the following years. ${ }^{15}$ As these recommendations were usually created by an international network of judges, perhaps 'it is not surprising that [they] are based on the

\footnotetext{
${ }^{9}$ E.g. Marc BühImann \& Ruth Kunz, Confidence in the Judiciary: Comparing the Independence and Legitimacy of Judicial Systems, 34 WEST EUROPEAN POLITICS 317 (2011); or for an overview see Marína Urbániková \& Katarína Šipulová, The Failed Expectations: Does the Establishment of Judicial Councils Enhance Confidence in Courts? (in this special issue).

${ }^{10}$ E.g. Maria Popova, Politicized Justice in Emerging Democracies: A study of Courts in Russia ANd Ukraine (2012).

${ }^{11}$ E.g. Mathieu Chemin, Do judiciaries matter for development? Evidence from India, 37 JOURNAL OF COMPARATIVE ECONOMICS 230 (2009); Stefan Voigt, Jerg Gutmann \& Lars Feld, Economic growth and judicial independence, a dozen years on: Cross-country evidence using an updated Set of indicators, 38 EUROPEAN JOURNAL OF POLITICAL ECONOMY 197 (2015); or J. Anthony Cookson, Economic Consequences of Judicial Institutions: Evidence from a Natural Experiment (2014), available at: https://extranet.sioe.org/uploads/isnie2014/cookson.pdf.

${ }^{12}$ See Nuno Garoupa \& Tom Ginsburg, Guarding the Guardians: Judicial Councils and Judicial Independence in 57 The American Journal of Comparative LaW 103 (2009) at 123; Daniel Smilov, EU Enlargement and the Constitutional Principle of Judicial Independence in Wojciech Sadurski, Adam Czarnota \& Martin Krygier, SPREADING Democracy and the Rule of LAW? THE IMPACt of EU ENLARGEMENT For the RULE of LAW 313 (2006); or David Kosař, Beyond Judicial Councils: Forms, Rationales and Impact of Judicial Self-Governance in Europe (in this special issue).

${ }^{13}$ See Smilov, supra note 12; Cristina E. Parau, The Drive for Judicial Supremacy, in JUDICIAL INDEPENDENCE IN TRANSITION 619 (Anja Seibert-Fohr ed., 2012); or David Kosař, Perils of JUdicial SElf-GovernMent IN TRANSITIONAL SOCIETIES 121-135 (2016).

${ }^{14}$ For an overview see Ann Power, Judicial Independence and the Democratic Process: Some Case Law of the European Court of Human Rights (International Bar Association Conference 2012). See also: ECtHR, 23 June 1981, Le Compte, Van Leuven and De Meyere v. Belgium, no. 6878/75; 7238/75; ECtHR, 28 June 1984, Campbell and Fell v. The United Kingdom, no. 7819/77; 7878/77; ECtHR, 22 June 1989, Lanbgorger v. Sweden, no. 11179/84, § 32.

${ }^{15}$ See Committee of Ministers of Council of Europe, Recommendation No. R (94) 12 on the Independence, Efficiency and the Role of Judges, particularly Principle I, Art. 2, par. C; Council of Europe, European Charter on the Statute for Judges, particularly Art. 1.3.; International Association of Judges, The Universal Charter of the Judge, particularly Art. 9. For more on the effect of 'soft law' on EctHR case law affecting judicial reforms in Europe see David Kosař, Nudging Domestic Judicial Reforms from Strasbourg: How the European Court of Human Rights shapes domestic judicial design in 13 UTRECHT L.R. 112 (2017).
} 
belief that the rule of law is best served by judicial autonomy. ${ }^{\prime 16}$ There are two main conclusions that can be drawn from these documents with regard to judicial recruitment. First, they posit that the process of recruiting judges should be conducted by a body with substantial judicial representation that is independent of political branches. Second, they hold a belief that this should serve the idea of recruitment based on merit, hence on the basis of qualification, integrity, ability, and efficiency of candidates.

Initially, these recommendations were meant to apply mainly to post-communist countries in need of reforming their judicial systems. The 1994 Recommendation adopted by the Committee of Ministers of the Council of Europe allowed for different arrangements, if these tasks were traditionally conducted by the government leaving old democracies in the clear. A later recommendation adopted in 2010 has not been as understanding. The document prescribes that if decisions about judicial careers are carried out by political authorities, these powers should be transferred to 'an independent and competent authority drawn in substantial part from the judiciary', ${ }^{17}$ which should be authorized to at least make recommendations or express opinions that relevant authorities should follow. This shift towards a greater involvement of judges in the administration of judicial careers has several common themes. First, it is based on a distrust towards political elites, conceiving insulation and de-politicization of the judiciary as a solution. ${ }^{18}$ Second, there is a belief that decisions about careers - and recruitment of judges in particular - establishes a connection between selectors and prospective judges, which motivates selectors to choose candidates who would not act contradictorily to their preferences. ${ }^{19}$ Third, it is based on the conviction that judges are on the one hand less dangerous than those in other branches, and on the other hand, that judges are more capable of securing continuity than changing governments or parliamentary majorities. ${ }^{20}$

In this paper I address two interconnected questions. First, how are judges in European countries recruited, and second, what is the role of judicial self-government in these processes given the rise of power of judges observable in recent decades? There is no

\footnotetext{
${ }^{16}$ Michal Bobek \& David Kosař, Global Solutions, Local Damages: A Critical Study in Judicial Councils in Central and Eastern Europe in 15 GERMAN L.J. 1257 (2014), at 1262; Parau, supra note 13, at 646-647.

${ }^{17}$ Committee of Ministers of Council of Europe, Recommendation CM/Rec(2010)12 on Judges: independence, efficiency and responsibilities, Art. 47.

18 E.g. Parau, supra note 13, at 621; or Franck Emmert, The Independence of Judges - A Concept Often Misuderstood in Central and Eastern Europe, 3 EUROPEAN JOURNAL OF LAW REFORM 405 (2001).

${ }^{19}$ Not necessarily would a selector be ever willing to utilize such capacity. For more on 'willingness' and 'capacity' to pressure courts see Popova, supra note 10.

${ }^{20}$ For the discussion on factors that play in favor of judges in this context see Alan Paterson, Power and Judicial Appointment: Squaring the Impossible Circle in Gee \& Rackley, supra note 1, particularly at 49 et seq. In terms of controlling access to a particular profession, judges are not that unique. See Keith M. MacDonald, The sociology of professions (1995).
} 
doubt there are differences between these processes in different countries - from the formal criteria one must meet to become a judge, to actors deciding about who gets to enter the judicial ranks. However, I choose to emphasize similarities between these processes. Judicial recruitment operates like a funnel where candidates are gradually eliminated until only one - or a few - remain. To become a judge, candidates need to meet certain eligibility criteria, they need to 'get on the selectors' radar'; to be considered for a position, they need to meet the selectors' expectations to be shortlisted and eventually selected for the job; and finally, they need to assume the office through some formal appointment procedure. ${ }^{21}$ By highlighting similarities in the process of recruiting judges, I aim to propose a framework that is applicable beyond the countries analyzed in this paper.

In addition, I argue that the recruitment process is - despite any merit-oriented efforts far from a perfect competition. Everyone involved has specific interests and preferences regarding who should become a judge, and this skews the process. Indeed, these interests should not be necessarily perceived with a negative connotation, they may be absolutely legitimate, even virtuous. Nevertheless, they shape the process in such a way that increases chances of some candidates at the expense of others - be it on the basis of gender, race, or any other characteristic. Contrary to belief entrenched in the numerous international documents discussed earlier, I contend that judges are as fallible as any other actor when it comes to recruiting new judges. As some research shows, their interests can be aligned with the ruling elite; ${ }^{22}$ they can have their own distinct interests stemming from the bureaucratic nature of the job, ${ }^{23}$ or from the genuine belief only they can properly exercise this task. ${ }^{24}$

In summary, in order to analyze judicial recruitment and its consequences we not only need to identify the actors involved in the process, but also study their preferences and pay attention to the stages of the process in which they shape the recruitment. As the recruitment process operates like a funnel where candidates are gradually eliminated, some attention needs to be paid particularly to the question of what type of candidates do not have real chances of making it through the whole process. For instance, if judicial actors involved in the selection know that a certain type of candidate will eventually be vetoed by political actors, they may eliminate a candidate themselves. By contrast, if judges manage to ensure that only a specific type of candidate makes it through the

\footnotetext{
${ }^{21}$ For a somewhat similar analogy see Mary L. Volcansek, Appointing Judges the European Way, 34 FORDHAM URB. L.J. (2007).

${ }^{22}$ E.g. Marc J. Ramseyer \& Eric B. Rasmusen, Why Are Japanese Judges so Conservative in Politically Charged Cases?, 95 The American Political SCIEnCE RevieW 331 (2001).

${ }^{23}$ On the bureaucratic nature of judicial careers in some judicial systems see for instance: CARLO GUARNIERI \& PATRICIA Pederzoli, THe Power of Judges (2002).

${ }^{24}$ E.g. Paterson, supra note 20.
} 
process, they may effectively constrain political actors' formal powers. Either way, it is not only important who is involved in the process, but also at what stage.

The paper proceeds as follows. In Part B, I discuss judicial recruitment in the broader context of the literature on judicial careers literature, with a focus on different models of judicial selection practices. Part $\mathrm{C}$ analyzes models of judicial recruitment found in Europe with special attention paid to the openness and competitiveness of judicial recruitment, as well as the actors playing a central role in these processes. Four models are identified and analyzed in this part, with a specific focus on the structure of the process and the gradual decrease of the number of potential candidates competing for the position. In Part D, I highlight the need to address not only how these processes work formally, but also how the motivations and incentives of the involved actors translate into the composition of judiciaries and their diversity. Part E concludes.

\section{B. Judicial Recruitment in a Broader Perspective}

The way in which judges are recruited is often perceived as an inherent feature of a particular model of judicial careers. In the bureaucratic model of the judiciary, judges traditionally enter the judicial system at the lowest level at a very young age and remain there for most of the remainder of their careers. In the professional model, judges are recruited after a relatively successful career in other legal profession, hence at a relatively higher age. Scholarly literature generally seems to highlight differences between models of judicial careers and models of judicial selection. In this paper I contend that in Europe these differences seem to be gradually vanishing, and that despite some differences there are notable similarities between seemingly distinct processes. In this Part I first present a brief overview of the literature focusing on the ideal-types of judicial careers, followed by an overview of different models of judicial recruitment.

\section{Models of Judicial careers}

There are two ideal-types of judicial careers described by the scholarly literature. A bureaucratic model of judicial career, ${ }^{25}$ also referred to as a 'career model', ${ }^{26}$ resembles a career path typically found in civil-service, ${ }^{27}$ and is typically found in countries with civil law tradition. According to Guarnieri and Pederzoli, ${ }^{28}$ judges in this model are usually recruited

\footnotetext{
${ }^{25}$ See Guarnieri \& Pederzoli, supra note 23; or Graham Gee, The Persistent Politics of Judicial Selection: A Comparative Analysis, in JUDICIAL INDEPENDENCE IN TRANSITION 121 (Anja Seibert-Fohr ed., 2012).

${ }^{26}$ Nuno Garoupa \& Tom Ginsburg, Hybrid Judicial Career Structures: Reputation versus Legal Tradition, 3 JOURNAL OF LEGAL ANALYSIS 411 (2011).

${ }^{27}$ See for instance: Volcansek, supra note 21; or Guarnieri, supra note 5.

${ }^{28}$ See Guarnieri \& Pederzoli, supra note 23, at 66-67; or Gee, supra note 25.
} 
directly from universities, without much emphasis on their previous experiences. Consequently, to ensure they have all the necessary skills, they are trained and socialized in the system - often in 'pre-judicial' positions as law clerks, so-called 'junior judges', ${ }^{29}$ or Rechtspflegers. ${ }^{30}$ Judges in bureaucratic judiciaries enter at the lowest rank and can work their way up the hierarchy, while their career prospects are dependent on superior or senior judges. Also, judges are usually generalists without expertise in any particular area of law, enabling them to perform satisfactorily anywhere the system needs them to. As a result, judges in bureaucratic judiciaries are to a large extent shaped by their superiors or more senior judges, which can lead to a self-perpetuation of attitudes, beliefs and practices within the judiciary, ${ }^{31}$ while 'it also helps to forge a common sense of identity within the judiciary. ${ }^{32}$ Additionally, the fact that judges' career prospects are dependent on their superiors can threaten their internal independence as they can be motivated to act loyally in order to be rewarded.

In common law judiciaries, becoming a judge is not simply a career choice but rather a 'kind of crowning achievement' ${ }^{33}$ achieved relatively later in professional life as a reward for a successful career in another legal profession. That is why these judiciaries are labelled as recognition judiciaries, ${ }^{34}$ or judiciaries with a professional model of judicial careers. ${ }^{35}$ Judges in this system are thereofre usually trained and socialized outside of the judicial system, and they are more often experts in a particular legal field rather than generalists. Unlike in a bureaucratic model, in recognition judiciaries judges do cannot reasonably expect to be promoted by their superiors, but their career prospects are rather dependent on political support. This makes them in theory more vulnerable to external pressures; which are counterbalanced through other mechanisms, such as life tenure. ${ }^{36}$

\footnotetext{
${ }^{29}$ By junior judges I mean, for the purposes of this analysis, positions found for instance in Czechia or Slovakia, which refer to a specific type of apprenticeship during which junior judges spend some time in a different division of the judicial system in order to become familiar with its inner workings. See for instance, Kosař, supra note 13, at 189 , who refers to them as 'judicial candidates', however it may be confusing to use this term in this context.

${ }^{30}$ Court officials with certain judicial powers in German speaking countries or countries influenced by the German legal culture. For instance, CEPEJ reports, supra note 7, use this term as well.

${ }^{31}$ See for instance: Michal Bobek, The Fortress of Judicial Independence and the Mental Transition of the Central European Judiciaries, 14 EUROPEAN PUBLIC LAW 99 (2008).

${ }^{32}$ Gee, supra note 25 , at 124 .

33 John H. Merryman, The Civil LaW Tradition: An Introduction to the Legal System of Western Europe and Latin AMERICA 34 (Stanford University Press, 1990).

${ }^{34}$ E.g.: Garoupa \& Ginsburg, supra note 26.

${ }^{35}$ Guarnieri \& Pederzoli, supra note 23; and Gee, supra note 25.

${ }^{36}$ John Ferejohn, Independent Judges, Dependent Judiciary: Explaining Judicial Independence, 72 SOUTHERN CALIFORNIA L.R. 353 (1998).
} 
Theory suggests that bureaucratic judges should be recruited through competitive process, whereas vacancies in recognition judiciaries are filled through executive appointments, where candidate's past achievements help a selector to justify their recruitment to the public. Yet, this distinction has only limited applicability in the real world, as both models often coexist along each other. ${ }^{37}$ According to Garoupa and Ginsburg, the choice of a model of judicial careers is determined rather by importance of reputation for a particular position, and not by a legal tradition dominant in any given jurisdiction. ${ }^{38}$ Consequently, we can observe trends that are contradictory to expectations raised by the two ideal-types. The lateral entry becomes more common for traditionally bureaucratic judiciaries as an attempt to prevent corporatist tendencies, such as reserved positions for judges socialized outside of the judiciary as it is in France or Spain. ${ }^{39}$ An opposite trend can be found in common law countries where judicial recruitment has traditionally been executive prerogative, but judges have become increasingly involved in the process of judicial recruitment; ${ }^{40}$ and even promotions are not that uncommon, as e.g. majority of current Justices at the Supreme Court of the United States previously served on lower courts. ${ }^{41}$

\section{Differentiating between models of judicial recruitment}

The fact that several models of judicial recruitment can occur in a single judiciary makes it particularly difficult to propose a sufficiently complex typology of different recruitment procedures. Even if we limit the scope of such an inquiry only to EU countries we can see a great variance. Indeed, several such attempts can be found. Volcansek focuses on the process through which judges are recruited, and differentiates between the civil service model of judicial recruitment, shared appointment and shared appointment with partisan quotas. ${ }^{42}$ In their bi-annual analysis of European judicial systems, the CEPEJ focuses on four

\footnotetext{
${ }^{37}$ A similar point can be found in Bell, supra note 5 , at 17.

${ }^{38}$ Garoupa \& Ginsburg, supra note 26; or NUNO GAROUPA \& TOM GINSBURG, JUdICIAL REPUTATION: A COMPARATIVE THEORY (2015).

${ }^{39}$ Guarnieri, supra note 5, at 171. See also discussion throughout Part C.

${ }^{40}$ See Van Zyl Smit, supra note 1; or Jan van Zyl Smit, 'Opening up' Commonwealth Judicial Appointments to Diversity? The Growing Role of Judicial Commissions, in DEBATING JUDICIAL APPOINTMENTS IN AN AGE OF DIVERSITY 70 (Graham Gee \& Erika Rackley eds., 2017). Also, the statement that $81 \%$ of Commonwealth countries have some kind of Commission playing a role in the selection of judges can be found in: Graham Gee \& Erika Rackley, Introduction: Diversity and the JAC's First Decade, in DEBATING JUDICIAL APPOINTMENTS IN AN AGE OF DIVERSITY 1 (Graham Gee \& Erika Rackley eds., 2017).

${ }^{41}$ See for instance: Denise Lu, Alicia Parlapiano \& Karen Yourish, Kavanaugh Followed the Narrow, Elite Path of Supreme Court Justices in NEW YORK TIMES, 10 July 2018, available at: https://www.nytimes.com/interactive/2018/ 07/10/us/politics/supreme-court-path-kavanaugh.html.

${ }^{42}$ See Volcansek, supra note 21 . It needs to be noted that in her analysis Volcansek does not separate ordinary judiciaries from apex and/or constitutional courts.
} 
factors: decisive authorities in the process, the presence or absence of compulsory initial training for judges, the competitiveness of the process, and whether there is an established procedure for other legal professionals. ${ }^{43}$ Oberto highlights actors deciding in the process, differentiating between executive nominations, recruitment through public elections, co-option by the judiciary, and through the committee-centered competitive process with the involvement of judges or academics. ${ }^{44}$ Finally, Garoupa and Ginsburg focus on the role of judicial councils in the process of recruiting judges. ${ }^{45}$ In addition, specifically for common law countries, MacNeill identifies three distinct models which all share nominations by the executive, but differ as regards the body empowered to select judges who are eventually appointed. According to this typology, this power can be exercised by the executive itself, it may require the approval of the legislature, or it can be decided by an independent judicial screening commission. ${ }^{46}$

As can be seen, there are different factors that can be highlighted when one looks at the process of judicial recruitment. When focusing on actors, Oberto's typology perhaps covers all known possibilities from a decisive say of the political branches, through involvement of the judiciary - by itself or through a specialized committee, to the selection of judges by the public. There are still several nuances that can be added. Oberto highlights the role of the executive among political branches, but there were examples when the power of selecting new judges has belonged to the parliament. In Slovenia, the National Assembly makes the final call upon the nomination of the Judicial Council. In Slovakia, until 2002, it was also the parliament that played a crucial role in the appointment of new judges. Importantly, in Czechia, although ministers hold formal powers over judicial appointments, it is court presidents who are perhaps the most crucial gatekeepers. ${ }^{47}$ Consequently, it is formally a system with executive appointments, but in fact, it more resembles a system where new judges are co-opted by the judiciary. Furthermore, even when the process is governed by judges, the co-optation can happen in a variety of ways. ${ }^{48}$ In France, Spain or Portugal it is judicial schools which effectively control who gets the opportunity to have the training necessary to hold judicial office. In the Netherlands, Slovakia or Poland, the role of gatekeeper is practically vested in judicial councils. Elsewhere, e.g. in Ireland, although

\footnotetext{
${ }^{43}$ See for instance: CEPEJ, supra note 7, at 81-112.

${ }^{44}$ See GiaComo Oberto, ReCRUtement ET FORMATION DES MAGISTRATS EN EUROPE. ETUde COMPARATIVE 13 (2003) as cited in Bell, supra note 5 .

${ }^{45}$ Garoupa \& Ginsburg, supra note 12 , at 119-120.

${ }^{46}$ See for instance the case of Ireland in Jennifer Carroll MacNeill, The Politics of Judicial Selection in IReland (2016); or Patrick O'Brien, Never Let a Crisis Go to Waste: Politics, Personality and Judicial Self-Government in Ireland (in this special issue).

${ }^{47}$ E.g. Adam Blisa, Tereza Papoušková \& Marína Urbániková, Judicial Self-Government in Czechia: Europe's Black Sheep? (in this special issue).

${ }^{48}$ See the discussion in Part C.
} 
judges formally have a substantial say in the process, the final decision is left to the executive. ${ }^{49}$

There are several reasons why we should pay attention to the processes through which judges are recruited. First, following the logic found in international recommendations, selection of a particular candidate can create certain ties between involved parties, hence threaten the judicial independence. Knowing whether it is the executive, a judicial body, their combination, or any other body can help us identify any potential threats. Second, compulsory training and socialization in the judiciary can ensure imprinting values, beliefs, attitudes, and practices on new judges. On the one hand, this can secure the effective transfer of knowledge from senior to junior members of the judiciary; on the other, it can prevent judiciaries from any new ideas and can protect the survival of habits not conducive to efficient and accountable justice systems. All in all, the ways in which the judges are recruited can have numerous implications on the actual performance of judicial systems.

\section{Structure of the process of judicial recruitment}

How strong particular actors are in the recruitment process is not simply determined by their involvement in the process, but also by the stage of the process in which they are involved. Despite many differences between models of judicial recruitment, they also share certain features. First and foremost, in the end, the process needs to separate winners and losers - those who are selected and appointed to the judicial office, and those who are not, despite their interest. Every recruitment process involves a number of potential candidates that gradually decreases - through their interaction with the selector - until only one (or possibly few) remain and are eventually appointed. In essence, the process operates as a funnel, as once it starts the number of candidates only reduces, and no one can enter the process from the outside. ${ }^{50}$ This analogy aims to help us identify and better understand critical junctions in the recruitment process where selector's preferences determine who remains in the competition for the judicial position, and similarly importantly, who is eliminated.

I propose dividing the process of recruitment into five different stages. First, in order to become a judge, one must meet the prescribed criteria to hold such an office, hence be eligible for a given position. Second, candidates need to be considered for the position by a selector, they need to 'get on the radar,' to be given a chance to compete for the position. Third, candidates need to meet certain criteria - both formal and informal - to be

\footnotetext{
${ }^{49}$ See particularly Part C.III.

${ }^{50}$ A similar analogy was previously used by Volcansek, supra note 21 , at 364 . Volcansek identified three stages of the process: a) certification, which 'derives a person's status in the structure of political opportunity, his opportunity costs, and political socialization;' b) selection, in which candidates and the selecting body interact; and c) role assignment, which gives legitimacy when a candidate formally assumes the office.
} 
shortlisted for the position by the selector. Only afterward does a selector make the final call and selects the best fit candidate for the judicial office. Finally, this person eventually assumes the office through a formal process of appointment. Indeed, not always are these stages easily distinguishable, and at times they even blend, but generally in order to become a judge, one must 'survive' all these critical junctions.

In the following sections, I identify and discuss these stages in four models of judicial recruitment found in Europe. These models were identified on the basis of two factors. The first is the formal openness of competition, i.e. dependency of the participation of any one candidate on the will of the selector. Czechia and Slovenia serve as examples for the 'closed' model of recruitment, as in these countries judges are picked seemingly 'out of thin air' by court presidents, and only afterwards they need to complete a formal process culminating in a successful appointment. Among open and competitive models I identified three distinct paths to the judiciary that can be found in more than one country. France, Spain and Romania serve here as examples for the model with a crucial role played by judicial schools. In the second model, central role is played by judicial councils - along other judicial self-government bodies. Such a model can be found in Slovakia, Poland and the Netherlands. The third model includes a specialized body empowered to select most suitable candidates, e.g. those found in Ireland or the United Kingdom. Indeed, these four models certainly do not exhaust the variations found in Europe, yet they show that commonly found models of judicial recruitment share certain similar features. ${ }^{51}$ It needs to be noted, I focus only on primary paths to the judiciary, hence the most common ways of becoming a judge. As was discussed above, it is not uncommon to find several different recruitment models within one judicial system. Possibilities for lateral entry will be therefore discussed rather as a complement to the typical ways in which judges in different jurisdictions are recruited. ${ }^{52}$

\footnotetext{
${ }^{51}$ For instance, Germany offers a completely different model where the crucial moment separating those who can eventually become judges and those who cannot takes place at state exams at the end of law graduates' university studies. See Fabian Wittreck, Judicial Self-Government in Germany: Resistance and the Roots of Counter-Resistance (in this special issue); Johannes Riedel, Recruitment, Professional Evaluation and Career of Judges and Prosecutors in Germany, in ReCRUITMENT, Professional EVAluATION AND CAREer of JUdGeS AND ProseCUtors IN EUROPE 69 (Giuseppe Di Federico ed., 2005); or Bell, supra note 5, at 108-173.

${ }^{52}$ For instance, in France there are numerous ways in which one may enter the judiciary. See Roger Errera, The Recruitment, Training, Career and Accountability of Members of the Judiciary in France in Di Federico, supra note 4 at 49-50; Bell, supra note 5, at 52-53.
} 


\section{Entering the judiciary through judicial schools}

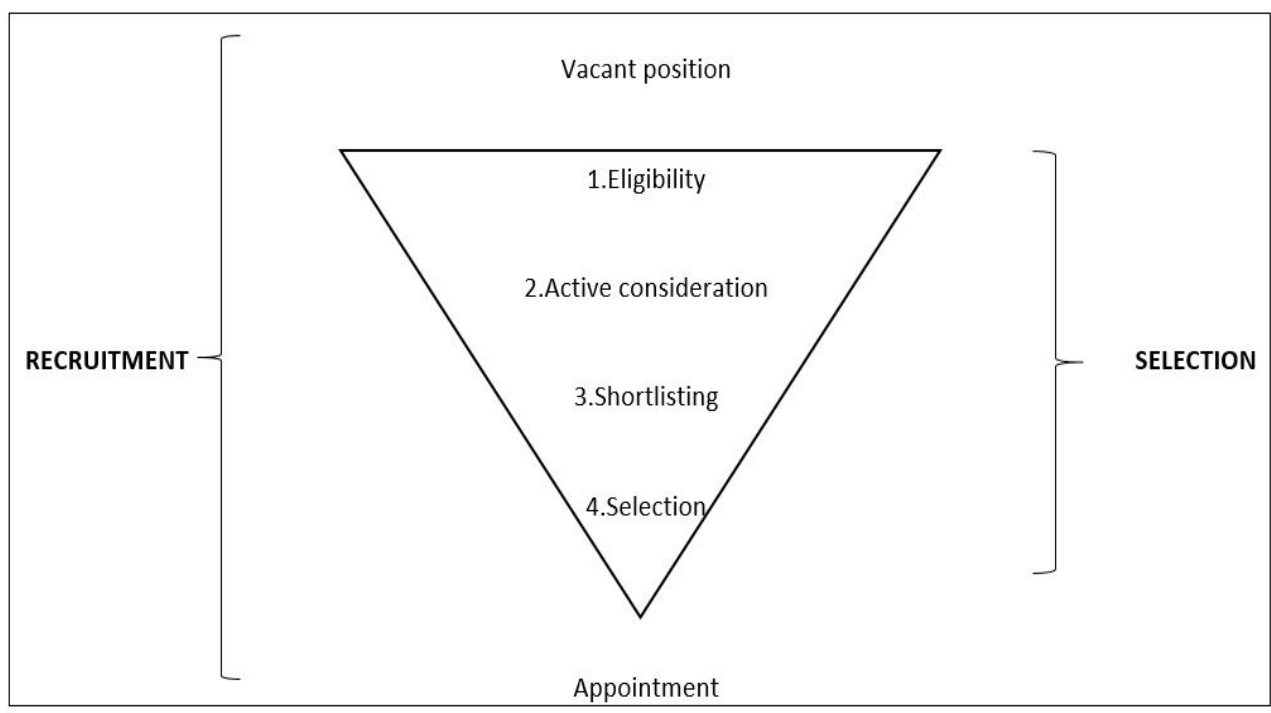

Figure 1. Visualization of the recruitment process

A prototype of a system of recruitment of judges through judicial schools can be found in France, where the École nationale de la magistrature (ENM) was founded more than half a century ago. ${ }^{53}$ It is based on the idea that the judicial profession is unique and requires specific training. At the same time, by preparing judges for their role in a particular environment it ensures the transfer of beliefs, attitudes and practices that help to build a certain common identity. ${ }^{54}$ The typical judicial career in this model starts practically right after the graduation when candidates pass a difficult competitive examination in order to complete a thorough education at the judicial school. Only afterward they can be appointed to a judicial position.

Eligibility criteria in this model are usually rather minimal. Candidates must hold a university degree, ${ }^{55}$ be of a certain age and be able to meet other formal criteria, such as holding a particular nationality, having a good moral character, and being physically able to work as a judge. Anyone meeting these prescribed criteria who aspires to work as a judge

\footnotetext{
${ }^{53}$ Antoine Vauchez, The Strange Non-Death of Statism: Tracing The Ever Protracted Rise of Self-Government in France (in this special issue).

${ }^{54}$ Errera, supra note 52, at 51-52.

${ }^{55}$ To apply to the French judicial school, ENM, candidates need to have any 4-year university degree in any subject, not necessarily a law degree. See Errera, supra note 52, at 45.
} 
can apply and be considered for the position. To be accepted in the program, candidates need to pass a difficult nation-wide examination aimed at thoroughly testing their knowledge and capabilities. The examination consists of written and oral parts. In Spain ${ }^{56}$ and Romania, ${ }^{57}$ candidates need to pass a test; in France, ${ }^{58}$ the written part includes drafting papers on a variety of legal topics covering different branches of law. Oral examinations are also used differently among the analyzed countries. In Spain, the emphasis is placed on hard knowledge, and candidates are expected to "sing" or "recite" their answers. ${ }^{59}$ Consequently, such an examination raises a concern that the procedure does not favor those who are intellectually or analytically best fit for the position, but rather candidates who excel at memorizing. ${ }^{60}$ In France and in Romania the oral exam is designed to address candidates' motivations, as well as their moral fitness to serve as judges.

Differences can be also found between bodies deciding in the process of admission to the school. Whereas in France it is decided by the Board of the ENM, dominated by the judges, ${ }^{61}$ in Romania ${ }^{62}$ and Spain ${ }^{63}$ this task is conducted by a special admissions board or by tribunals, respectively, both controlled by their respective judicial councils consisting of judicial members with representation from academia, law practitioners, court staff or representatives of the trainees at the school. Passing the examination is a difficult task. In France, it was reported that only about $10 \%$ of candidates manage to be successful. ${ }^{64}$ In Spain only about $5 \%$ of applicants are eventually selected as the preparation takes up to four years and is extremely demanding. ${ }^{65}$ Training at the judicial schools also differs between the countries. In Spain, candidates must undergo a 6-month training concerned

\footnotetext{
${ }^{56}$ Maria Poblet \& Pompeu Casanovas, Recruitment, Professional Evaluation and Career of Judges and Prosecutors in Spain in Johannes Riedel, Recruitment, Professional Evaluation and Career of Judges and Prosecutors in Germany, in Recruitment, Professional Evaluation and Career of Judges and Prosecutors in Europe 193 (Giuseppe Di Federico ed., 2005).

${ }^{57}$ Ramona Coman \& Cristina Dallara, Judicial Independence in Romania, in JUDICIAL INDEPENDENCE IN TRANSITION 835, 848 (Anja Seibert-Fohr ed., 2012).

${ }^{58}$ Errera, supra note 52 , at 48 .

${ }^{59}$ Poblet \& Casanovas, supra note 56, at 193.

${ }^{60}$ Aida Torres Pérez, Judicial self-government and judicial independence: the political capture of the General Council of the Judiciary in Spain (in this special issue).

${ }^{61}$ Errera, supra note 52, at 52.

${ }^{62}$ See Bianca Selejan-Gutan, Romania: Perils of a 'Perfect Euro-Model' of Judicial Council (in this special issue).

${ }^{63}$ Poblet \& Casanovas, supra note 56, at 194.

${ }^{64}$ Errera, supra note 52, at 45.

${ }^{65}$ Poblet \& Casanovas, supra note 56, at 194.
} 
with theoretical and practical skills, followed by a training period working at a court. ${ }^{66}$ In France, candidates for judicial offices go through complex training consisting not only of courses and seminars at the school and 1-year internships at the courts but also of internships with non-judicial institutions and barristers. In Romania, candidates must first complete a 2-year complex training at the school before being appointed by the Romanian judicial council for a 6-year training period to work as 'junior judges' or 'junior prosecutors'.

Even the successful completion of all mandatory training does not secure a judicial position. French as well as Romanian judges first need to pass another examination that, together with their evaluations from their internships or probationary periods, respectively, determine their final ranking. In France, this examination is controlled by an independent panel appointed by the Ministry of Justice, ${ }^{67}$ and only few fail to pass it. ${ }^{68}$ Afterward, successful candidates are nominated by the French judicial council, first for a 4month probationary period at a different court in order to be eventually appointed by the president of the country to the judicial office. In Romania, the judicial council also plays a role, as it nominates, in a non-discretionary process, candidates for appointment by the president. ${ }^{69}$ In Spain, the appointment powers are vested to the Plenary of the Council, which is argued to pose a risk of arbitrary decision-making based on ideological considerations rather than candidates' abilities. ${ }^{70}$

There seems to be several regularities in the model of judicial recruitment through judicial schools. First, the most important step for a candidate is to successfully pass the entry examination to the judicial school, hence move from being actively considered to a shortlist of candidates actually lucky enough to obtain the necessary training. Second, even though the model has a strong preference for selection based on candidates' capacity and merit, the requirements of the process which is difficult, time-consuming and with uncertain results may favor candidates with certain socio-economic characteristics and not necessarily those best equipped to work as judges. Interestingly, in all three jurisdictions, the majority of judges are women, ${ }^{71}$ who may be more willing to endure this uncertainty because of their stronger preference for work-life balance eventually offered by the

\footnotetext{
${ }^{66}$ Torres-Pérez, supra note 60.

${ }^{67}$ Errera, supra note 52, at 53.

${ }^{68}$ Errera, supra note 52, at 54, Table 2-4.

${ }^{69}$ Coman \& Dallara, supra note 57 , at 850 .

${ }^{70}$ Torres-Pérez, supra note 60.

${ }^{71}$ As of 2014 , the share of women in the judiciary in Romania was at $74 \%$, in France $62 \%$ and in Spain $52 \%$. See CEPEJ, supra note 7.
} 
judicial position. ${ }^{72}$ In addition, in France the process led to an over-representation of middle-class candidates, ${ }^{73}$ at times with family ties in the judiciary ${ }^{74}$ Third, although judicial councils do not play central roles in these processes, they exercise at least some control over who enters the judiciary. And finally, as the extensive education and socialization among judges provide a fertile ground for the rise of corporatist attitudes, they are sometimes counter-balanced by promoting paths for lateral entry to other legal professionals. ${ }^{75}$ In Spain, about $25 \%$ of magistrate seats are reserved for lawyers with at least 10 years of experience; ${ }^{76}$ in France the education at the ENM is open to civil servants, those who served as elected members of local councils, as well as those with a doctorate in law or research and teaching experience at the university. ${ }^{77}$

\section{Recruitment controlled by judicial self-government bodies}

The model of judicial recruitment where the crucial role is played by bodies of judicial selfgovernment often shares similarities with the model with the central role of the judicial school. Often these procedures are competitive, as they are in Slovakia or the Netherlands; often they come with mandatory training at a specific institution, as it is in Poland or the Netherlands. Though, it needs to be noted, the access to mandatory training is controlled not by judicial schools nor any national authority, but rather to judicial self-government bodies on the level of individual courts. In addition, decisions made at a non-national level are later reviewed by judicial councils which effectively serve as crucial gatekeepers.

In the three countries analyzed in this section, the eligibility criteria slightly differ. Slovakia has the simplest rules. Candidates for judicial office need to be 30 years old, meet the usual criteria such as nationality and clear police records, need to have a law degree and have passed an exam authorizing them to exercise the legal profession. ${ }^{78}$ Poland and the

\footnotetext{
${ }^{72}$ E.g. Madlena Duarte, Paula Fernando, Conceiçãcao Gomes \& Ana Oliveira, The Feminization of the Judiciary in Portugal: Dilemmas and Paradoxes, 10 UTRECHT LAW REVIEW 29 (2014).

${ }^{73}$ For France see Doris Marie Provine \& Antoine Garapon, The Selection of Judges in France: Searching for a New Legitimacy, in Malleson \& Russell, supra note 5. For Spain see for instance: Bell, supra note 5, at 190, where candidates from less prosperous regions with fewer professional opportunities were also particularly overrepresented.

${ }^{74}$ Bell, supra note 5, at 53.

${ }^{75}$ In France, entering the judiciary right after university remains the most common path, however there have been efforts to promote alternative paths. See Antoine Garapon \& Harold Epineuse, Judicial Independence in France, in JUDICIAL INDEPENDENCE IN TRANSITION 273, 281 (Anja Seibert-Fohr ed., 2012).

${ }^{76}$ Poblet \& Casanovas, supra note 56, at 195.

${ }^{77}$ Errera, supra note 52, at 47-48.

${ }^{78}$ For the purpose of participation in the judicial selection procedure, judicial, advocate's, prosecutor's or notary exam all count as equal.
} 
Netherlands adds to the criteria the requirement related to previous professional training. Polish judges need to be at least 29 years old, have a law degree, plus, they need to have completed a traineeship at the judicial school and/or served as probationary judges for at least 3 years. Recruitment from the positions of probationary judges has recently been the most common path to judicial office. ${ }^{79}$ In the Netherlands, the first phase of a judge's career very much resembles careers in systems with judicial schools. After graduation, candidates apply to serve as a 'judicial public servant in training', ${ }^{80}$ they need to pass a test on intelligence, a psychological examination and an oral exam with the National Selection Committee, which consists of 22 members appointed by the Dutch judicial council. ${ }^{81}$ Reports suggest the process may be skewed in favor of candidates with particular characteristics, as minority candidates have greater problems to pass the written exams. ${ }^{82}$ Candidates who manage to pass need then to complete a 6-year training consisting of 38 months of training at the court, 10 months of in-depth education at the Training and Study Center for the Judiciary (SSR), followed by a 2 -year internship outside of the judiciary. ${ }^{83}$

To be considered for a judicial position, candidates need to apply to the process. In both Poland and the Netherlands judges apply directly to the court where there is a vacant position. In Poland, the court president administering applications passes them to the college of the court for the assessment of their qualifications. Subsequently, the list of candidates is considered by the assembly of the court, which takes a vote and hence creates a shortlist of possible candidates. In the Netherlands, candidates are interviewed by judges of the court to determine whether candidates fit in the organization. ${ }^{84}$ After that, the management of the court, possibly with advice from the court's assembly, prepares a ranked list of 3 candidates for appointment, which is sent to the judicial council.

In Slovakia, until 2017, candidates similarly applied directly to courts. As this practice was on the one hand rather slow, leaving courts with vacant positions for a considerable amount of time, and on the other produced results that favored candidates who previously served at particular courts, ${ }^{85}$ these rules were changed. Since then, selection procedures

79 See Anna Śledzińska-Simon, The Rise and Fall of Judicial Self-Governement in Poland: On Judicial Reform Reversing Transition (in this special issue).

${ }^{80}$ Philip M. Langbroek, Recruitment, Professional Evaluation and Career of Judges and Prosecutors in the Netherlands in Di Federico, supra note 5, at 164.

${ }^{81}$ See Elaine Mak, Judicial Self-Government in the Netherlands: Demarcating Autonomy (in this special issue).

${ }^{82}$ Roel De Lange, Judicial Independence in the Netherlands, in JUDICIAL INDEPENDENCE IN TRANSITION 231, 243 (Anja Seibert-Fohr ed., 2012).

${ }^{83}$ Langbroek, supra note 80, at 168.

${ }^{84} / d$. at 168 .

85 Samuel Spáč, by the Judges, for the Judges: The study of Judicial Selection in Slovakia (Dissertation Thesis, Comenius University, 2017). 
are administered at the level of second-instance courts, are held once a year, and are intended to fill all expected vacancies in the region. ${ }^{86}$ Five-member committees appointed by the president of the Slovak judicial council are in charge of the selection. They consist of two members nominated by the judicial council, two members nominated by the Minister of Justice, and one member elected by the college of presidents of councils of judges in the given region. The procedure consists of a series of written exercises, psychological evaluation and the interview with the committee, which decides about its content. In order to pass all the requirements, candidates need to score at least $60 \%$ in each phase of the process. The final ranking of the candidates is then created by totaling the grades from all phases of the procedure. $^{87}$

In the final stages of these processes in all three countries, successful candidates are considered by judicial councils, which nominate them for appointment to the executive branch. The Dutch council receives a ranked list of three candidates and passes it to the government which appoints the highest ranked candidate. In Poland and Slovakia, although councils interfere with the nomination process rather rarely, there have been some controversies. $^{88}$ In addition, both the Polish and the Slovak council consider security screenings prepared by the executive branch checking for candidates' 'immaculate character. ${ }^{89}$ The appointment process in both countries has seen some controversies. In 2014, Slovak President Andrej Kiska initially refused to appoint a candidate because of concerns about the fairness of the selection procedure and asked the council to reconsider. Yet, when the council nominated the candidate again, Kiska appointed her to office. ${ }^{90}$ Unlike in Slovakia, Polish presidents have managed to refuse the appointment of nominated judges despite the will of the council. In 2008, President Lech Kaczynski refused to appoint 10 judges without any justification; ${ }^{91}$ and the same happened in 2016 when President Andrzej Duda refused to appoint another 10 candidates. $^{92}$ As neither council can actually overrule president's decision, the observed difference cannot be easily explained by different institutional setting and is rather a consequence of different factors.

\footnotetext{
${ }^{86}$ There are eight regional courts in Slovakia. In each of the regions there are five to eight district courts.

${ }^{87}$ For more detailed description of all phases see Spáč, supra note 85 , at 92-94.

${ }^{88}$ For more see Samuel Spáč, Kariérny postup na vyššie súdy: pod kontrolou predsedov súdov, in NEDOTKNUTEL'Ní? POLITIKA SUDCOVSKÝCH KARIÉR NA SLOVENSKU V ROKOCH 1993-2015 121 (Erik Láštic \& Samuel Spáč eds., 2017); Adam Bodnar \& Lukasz Bojarski, Judicial Independence in Poland, in JUDICIAL INDEPENDENCE IN TRANSITION 667,686 (Anja Seibert-Fohr ed., 2012).

${ }^{89}$ For more see Erik Láštic and Samuel Spáč, Slovakia / Slovaquie in 26 EUROPEAN REVIEW OF PUBLIC LAW 1201 (2014); or Samuel Spáč, Katarína Šipulová \& Marína Urbániková, Capturing the Judiciary from Inside: The Story of Judicial Self-Government in Slovakia (in this special issue); and Bodnar \& Bojarski, supra note 88, at 679-680.

${ }^{90}$ For more see Spáč, supra note 85 , at 94.

${ }^{91}$ For more see Bodnar \& Bojarski, supra note 88, at 687, 690-693; Śledzińska-Simon, supra note 79.

${ }^{92}$ See Sledzinska-Simon, supra note 79.
} 
The systems of judicial recruitment analyzed in this section share several features. Most importantly, the process of selection involves three actors. First, there is a selection procedure at a non-national level, either at individual courts or at the regional level, as it is in Slovakia. Second, a shortlist of successful candidates is passed to the judicial council, which rarely interfere. Finally, the appointment rests in the hands of the executive intervening in the process only sporadically, leaving the major responsibility at the nonnational level. As a consequence, even though all analyzed systems offer possibilities of lateral entry, they seem to be rather marginal. In Poland, it was estimated that only 15$20 \%$ of new judges come from outside of the judiciary, ${ }^{93}$ and judicial recruitment practices in Slovakia also showed a strong preference for candidates socialized in the system. ${ }^{94}$

\section{Recruitment of judges through specialized bodies}

The introduction of specialized bodies empowered to recruit judges in the United Kingdom and Ireland may be one of the strongest indicators of the rise of judicial self-governance in Europe and around the world. Ireland created its Judicial Appointments Advisory Board (JAAB) in 1995. It consists of 11 members, six of whom are judges, securing a narrow judicial majority in the body. ${ }^{95}$ The UK's Judicial Appointments Commission (JAC) ${ }^{96}$ started functioning a decade later, in 2006. It consists of 15 members of whom only six are judges, and only eight all together are lawyers. Additionally, not only are judges in the minority, the JAC is chaired by one of its lay members. Importantly, despite seeming similarity, the two bodies serve considerably different roles, which may be traced to rationales of their respective establishments. The Irish JAAB was 'not a product of policy preferences, but rather a reaction to political crisis ${ }^{\prime 97}$ spurred by a political disagreement over appointments of two senior judges causing the reform to fail to diminish political control over the process of judicial recruitment. In the UK, the executive gave up its powers on the basis of genuine

\footnotetext{
${ }^{93}$ See Sledzinska-Simon, supra note 79.

${ }^{94}$ Spáč, supra note 85 .

${ }^{95}$ For composition see MacNeill, supra note 46.

${ }^{96}$ When refering only to the Judicial Appointments Commission responsible for appointments in England and Wales, I purposefuly omit the Northern Ireland Judicial Appointments Commission (NIJAC) and the Judicial Appointments Board for Scotland (JABS) that fulfill the same task in other parts of the UK. Also, it needs to be noted that the JAC is responsible only for appointments to the Court of Appeal and High Court, while the appointments to the UK Supreme Court happen in a different regime. See van Zyl Smit, supra note 1, at 206-207.

${ }^{97}$ MacNeill, supra note 46 , at 88 .
} 
belief that weakening of the political influence ${ }^{98}$ would help to improve the judiciary and increase diversity of the judicial bench. ${ }^{99}$

The introduction of specialized bodies fundamentally altered the process of judicial recruitment in both countries. Judges in the UK were in the past selected through such nontransparent procedures that even the persons being considered for judicial positions did not know they were being talked about. ${ }^{100}$ Currently, to get on selector's radar in the UK, candidates need to apply and demonstrate their interests in working in the judiciary. As both countries are still recognition judiciaries, eligibility criteria are considerably higher than in continental Europe. Candidates in Ireland must be practicing lawyers for at least 10 years, ${ }^{101}$ in the UK it is required to have at least 5 or 7 years of professional experience in the legal field. ${ }^{102}$

After the application the crucial stages of the recruitment process are administered by these specialized bodies, however their respective roles differ. While in Ireland the JAAB only prepares a shortlist of candidates and the actual selection rests in the hands of political actors, the JAC operating in England and Wales is in fact responsible for picking those who are appointed. The Irish JAAB assesses candidates' general suitability on the basis of their applications, including information regarding their education, qualifications, and professional experiences. It then presents a list of the seven candidates it perceives to be fit for the office to the Minister of Justice. In the past, the body played a rather passive role, serving more as a screening body than a genuine gatekeeper, presenting not only seven candidates but all those who were not deemed 'suitable. ${ }^{103}$ Recently the body has started to play a more substantive role, recommending fewer candidates for the judicial office, ${ }^{104}$ or even none, as was reported to have happened on one occasion in $2016 .{ }^{105}$ In the UK, after the application the JAC sifts candidates based of their provided selfassessments, as well as on two reference letters focusing on their professional, personal or judicial qualifications. For larger selection procedures, candidates may also need to take a

\footnotetext{
${ }^{98}$ Although the process was perceived as de-politicized and merit-based, political considerations seemed to matter. See Chris Hanretty, The Appointment of Judges By Ministers: Political Preferment in England, 1880-2005 in 3 JOURNAL OF LAW AND COURTS 305 (2015).

${ }^{99}$ See van Zyl Smit, supra note 1, at 14.

${ }^{100}$ For more on these practices see van Zyl Smit, supra note 1, at 13.

${ }^{101}$ For more information see https://aji.ie/the-judiciary/appointment-to-judicial-office/.

${ }^{102}$ For more information see https://www.judicialappointments.gov.uk/eligibility-legally-qualified-candidates.

${ }^{103}$ MacNeill, supra note 46, at 89, 127-128.

${ }^{104}$ MacNeill, supra note 46, at 98.

${ }^{105}$ See O'Brien, supra note 46.
} 
qualifying test and have a telephone interview. Those who successfully get 'shortlisted' are invited for a 'Selection Day' consisting of an interview with a 3-member committee examining the candidates' performance in hypothetical scenarios or role plays. ${ }^{106}$

The selection of judges in the UK from the shortlist of candidates is determined in consultation with the person who previously held the vacant position or with someone who is considered to have 'other relevant experience'. ${ }^{107}$ Final decisions are made by the Selection and Character Committee, which consists of JAC members who take into account all the accumulated assessments before selecting one candidate for each vacancy. Interestingly, since 2013, in case of a tie between two or more candidates in terms of merit, the JAC should select a candidate to enhance the diversity of the judicial bench. ${ }^{108}$ In Ireland, the final selection does not happen in the specialized body, but as aforementioned it is the Minister who, after a discussion with the Attorney General and the Prime Minister (Taoiseach), presents the selected name to the Cabinet for formal approval. Although the government is not obliged to select any candidate from the list, it usually does so. When in 1998 the government wanted to appoint a candidate that the $J A A B$ deemed unsuitable, members of the JAAB threatened to resign, effectively protecting the significance of the body in the process of recruiting judges. ${ }^{109}$ The appointment rests in the hands of political bodies - in Ireland judges are eventually appointed by the President, in the UK by the Lord Chancellor, who can reject a recommendation and as the JAC to reconsider, but must provide written reasons for such action.

In summary, judicial recruitment through specialized bodies have managed to curtail traditional political influence over the process and have allowed judicial actors to effectively control entrance to the judiciary. Nevertheless, in Ireland the merit principle seems to be undermined by the fact that greater chances of success in the process have candidates who are known by crucial decision-makers. ${ }^{110}$ In addition, the reformed processes have so far failed to curb other traditional biases or create more diverse and representative benches. As of 2014 only about 30\% of judges in both judiciaries were female. ${ }^{111}$ Also, reports confirm that in the UK the same applies to ethnic or racial

\footnotetext{
${ }^{106}$ For more information about the process see https://www.judicialappointments.gov.uk/overview-selectionprocess.

${ }^{107}$ For more information see https://www.judicialappointments.gov.uk/statutory-consultation.

${ }^{108}$ For more see https://www.judicialappointments.gov.uk/equal-merit-provision.

${ }^{109}$ O'Brien, supra note 46.

${ }^{110}$ MacNeill, supra note 46, at 151.

${ }^{111}$ CEPEJ, supra note 7, at 101.
} 
minorities, ${ }^{112}$ urging some scholars to call for quotas to balance the bias favoring candidates from dominant identity groups. ${ }^{113}$

\section{Recruiting judges out of sight}

In Czechia and Slovenia, the process of judicial recruitment is much less visible and less structured than in the previously described cases. Paradoxically, this eventually serves for the benefit of judicial self-governance bodies, because it is court presidents who are the most crucial actors in the process. This happens because the political bodies - the president in Czechia and the parliament in Slovenia - who are empowered to appoint judges traditionally act more as notaries confirming decisions made elsewhere than as actual gatekeepers. Consequently, as crucial decisions are made out of sight, to obtain a proper understanding of these recruitment processes it may be necessary to have access to information about their informal parts. Otherwise, it may be impossible to identify candidates considered for the job, as well as to recognize how they are eventually selected.

The eligibility criteria in both countries described in this section are fairly similar. Candidates need to have obtained a law degree, must be 30 years of age and must meet some common criteria, such as nationality or 'good character.' Slovenian judges additionally need to have at least 3 years of professional experience in law, ${ }^{114}$ while Czech judges need to have passed a special judicial exam or the equivalent. ${ }^{115}$ In the following stages, it is the court presidents who are the most important actors. In Slovenia, court presidents make a preliminary reasoned selection of candidates, which they submit to the Judicial Council. The criteria that judges use to draw up a shortlist or determine who the candidates are seem to be hidden from the public eye. ${ }^{116}$ Czech court presidents also enjoy a great amount of discretion in the process. There are no national criteria for the selection procedures, hence they may differ from one court to another. At some courts it seems that court presidents hand-pick new judges, elsewhere court presidents have opted for selection procedures based on tests conducted by the Judicial Academy. ${ }^{117}$

\footnotetext{
${ }^{112}$ See https://www.judiciary.uk/wp-content/uploads/2018/07/judicial-diversity-statistics-2018-1.pdf.

${ }^{113}$ Malleson, supra note 7, at 281.

${ }^{114}$ Cristina Dallara, Judicial Reforms in Transition: Legacies of the past and dominant political actors in postcommunist countries, 1 IRSIG-CNR WORKING PAPER 10 (2007).

${ }^{115}$ For the purpose of consideration for a judicial position, candidates can have passed exams authorizing them to work in different legal professions, such as advocates, notaries or executors.

${ }^{116}$ See Matej Avbelj, Contextual Analysis of Judicial Governance in Slovenia (in this special issue).

${ }^{117}$ Blisa, Papoušková \& Urbániková, supra note 47.
} 
The process of appointment is also fairly similar in both countries. In Czechia, the minister formally nominates candidates for judicial offices on behalf of the government but does so upon request from the court president. Eventually, judges are appointed by the president of the country. Slovenian judges are nominated for their offices by the judicial council, which does so based on criteria adopted together with the Ministry of Justice. Appointment rests in the hands of the parliament, which usually confirms proposed candidates without any substantive discussion. This suggests 'a certain balance' between the judicial and the political body. ${ }^{118}$ Although, there have been few instances reported when the National Assembly declined to appoint proposed candidates despite criticism from experts and the general public, in at least one of these cases the unsuccessful candidate had served as an attorney, and hence aimed to enter the judiciary from the outside. $^{119}$

In summary, in this model judicial self-governance bodies seem to enjoy considerable discretion despite the fact that formal powers belong to politicians. Because the recruitment process happens in a rather nontransparent way, judicial bodies can greatly benefit from the information asymmetry they have vis-à-vis political bodies. The model provides a fertile ground for favoritism and selection based on criteria other than merit, as court presidents serve as de facto unrestrained gatekeepers. Whether they opt to concentrate such powers in their own hands, or whether they employ competitive procedures or make their decisions in consultation with other judges of the court is largely dependent on their will. The same applies to the openness of the judiciary to legal professionals working in other fields. In both countries, eligibility criteria suggest there is an option of recruiting judges laterally, however the actual openness is once again dependent on individual actors. Based on this, it can be reasonably hypothesized that candidates working in the judiciary as law clerks or 'junior judges' may have greater chances of being appointed, hence the crucial moment in judges' careers may happen at earlier stages of their careers - when they are recruited for junior positions, or when they are taking the required judicial exam. ${ }^{120}$ Paradoxically, the Slovenian example also shows that politicians may at times protect the judiciary from outsiders, even when the judiciary itself proposes such a candidate.

\footnotetext{
${ }^{118}$ Cristina Dallara, Smoother Judicial Reforms in Slovenia and Croatia: Does the Legacy of the Past Matter?, in Democracy and Judicial Reforms in South-EASt EuRope: BetWeen the EU and the Legacies of the Past 31, 39 (Cristina Dallara ed., 2014).

${ }^{119}$ Dallara, supra note 118, at 38-39; Avbelj, supra note 116.

${ }^{120}$ For more on 'junior judges' and their chances to become judges in the Czech system see Kosař, supra note 13, at 189 .
} 


\section{Analyzing judicial recruitment: taking actors and their motivations into account}

The discussion in the previous Part showed that different systems tend to favor different candidates. While the recruitment through judicial schools leads to over-representation of women and middle-class candidates, models where a crucial role is played by judicial selfgovernment bodies at non-national level tend to favor those with ties in the given environment. Traditional recognition judiciaries have, on the other hand, suffered from being elitist and unrepresentative of their societies. The particular composition of the judicial bench is a consequence of the interplay between motivations of selectors (who they search for), and candidates (who seek a judicial job) in the context of a specific institutional design (who decides in what stage and how much discretion they enjoy).

I argued that judicial recruitment operates as a funnel where the number of candidates gradually decreases until only one (or few) remain in the competition and are eventually appointed to the judicial office. This process has several critical junctions - eligibility, active consideration, shortlisting, selection and appointment - which effectively shape the outcome of the judicial recruitment process. Because of that it is important to look beyond institutions and the legal framework and take into consideration the motivations of involved actors. For instance, if eligibility criteria invite candidates from other legal professions, yet their chances of 'surviving' the competition would be considerably small, as they may not meet the informal criteria set out by a selector, a fairly small number of candidates for lateral entry may be misunderstood as a lack of interest of such candidates for judicial positions. Similarly, participation in the recruitment process may be too costly for certain groups of candidates causing over-representation of particular parts of the society on the judicial bench. In addition, even if the process of recruitment was a perfect rank-order tournament in which candidate compete against one another, ${ }^{121}$ their chances may be skewed because selection criteria may hold latent bias favoring some groups of candidates at the expense of others, incorrectly suggesting differences between them while disregarding possible benefits of a more diverse judiciary.

In an ideal case, and in line with the merit-principle emphasized in 'soft law' standards, an output of the recruitment process should be a result of a 'concern for correctly ascertaining the competence. ${ }^{122}$ In general, at each of the critical junctions, candidates need to persuade selecting bodies they are better fit than their competitors to perform the judicial function. Yet, competence may be only one of the many considerations selectors

\footnotetext{
${ }^{121}$ E.g. Hanretty, supra note 98; Stephen Choi \& Mitu Gulati, A Tournament of Judges? In 92 CALIFORNIA L.R. 299 (2004); Jordi Blanes I. Vidal \& Clare Leaver, Are Tenured Judges Insulated from Political Pressure? In 95 JOURNAL OF Public ECONOMICS 570 (2011); or Martin R. Schneider, Judicial Career Incentives and Court Performance: An Empirical Study of the German Labour Courts, 20 EUROPEAN JOURNAL OF LAW AND ECONOMICS 127 (2005).

122 Karen J. Alter, Agents or Trustees? International Courts in their Political Context in 14 EUROPEAN JOURNAL OF INTERNATIONAL RELATIONS 33, 42 (2008).
} 
make. To put it differently, selectors always have some preferences, from normatively desirable through those less legitimate to possibly latent ones. Selectors may pay attention to candidates' ideological positioning ${ }^{123}$ in order to secure certain political influence over the courts; ${ }^{124}$ or they can pursue other objectives such as diversity and representativeness of the bench, ${ }^{125}$ particularistic interests, ${ }^{126}$ or partisan considerations. ${ }^{127}$

The assumption that selectors always have motivations is particularly important for a proper understanding of how judicial recruitment works in the age of judicial selfgovernment. ${ }^{128}$ Whether recruiting powers belong to political branches or the judiciary, the process in which selectors equip new judges with considerable powers establishes a certain connection between them. ${ }^{129}$ There are several reasons why the danger of transferring these powers to the hands of judges should not be underestimated. Judges, just like any other group of actors, can have shared interests which can be translated into the composition of the judiciary. Indeed, they are not inevitably harmful - they may be based on reasonable, even virtuous, expectations about the role of the judiciary. Nevertheless, there is a substantial amount of evidence suggesting that actors within judiciaries may prove to be as dangerous as political actors, although their interests may

\footnotetext{
${ }^{123}$ E.g. Hanretty, supra note 98; Jeffrey A. Segal \& Harold J. Spaeth, The Supreme Court and the Attitudinal Model Revisited (2002).

${ }^{124}$ See particularly 'government control regime' in Rachel E. Bowen, Judicial Autonomy in Central America: A Typological Approach in 66 Political ResearCH QUARTERLY 831 (2013). For current developments in Central Europe see Adam Bodnar, Europe can save Poland from darkness in POLITICO, 9 April 2018, available at: https://www.politico.eu/article/poland-judiciary-rule-of-law-europe-must-intervene/; David Kosař \& Katarína Šipulová, The Strasbourg Court Meets Abusive Constitutionalism: Baka v. Hungary and the Rule of Law in 10 HAGUE JoURNAL ON THE RULE OF LAW 83 (2018); or Bojan Bugaric \& Tom Ginsburg, The Assault on Postcommunist Courts in 27 JoURNAL OF DEMOCRACY 69 (2016). For other parts of world see Raul A. Sanchez-Urribarri, The Politicization of Latin American Judiciary via Informal Connections, in LEGITIMACY, DeVELOPMENT AND CHANGE: LAW AND MOdeRNIZATION RECONSIDERED 307 (David K. Linnan, ed., 2012); Fombad, supra note 2; Alexander Stroh, Consequences of Appointment Policies for Court Legitimacy in Benin: A Network Analysis Approach, 281 GIGA WORKING PAPER (2016); or Voeten, supra note 3.

${ }^{125}$ E.g. Malleson, supra note 1; Jeffrey D. Jackson, Beyond Quality: First Principles in Judicial Selection and their Application to a Commission-Based Selection System in 34 FORDHAM URBAN L.J. 125 (2007).

${ }^{126}$ Spáč, Šipulová \& Urbániková, supra note 89.

${ }^{127}$ See Simone Benvenuti \& David Paris, Judicial Self-Government in Italy: Merits, Limits and the Reality of an Export Model (in this special issue); Başak Çalı \& Betül Dürmuş, Judicial Self-Government as Experimental Constitutional Politics: The Case of Turkey (in this special issue).

${ }^{128}$ Kosař, supra note 12.

${ }^{129}$ Such relationships can be framed within Principal-Agent theory. See Voeten, supra note 3. Although for the study of judges some authors recommend rather the idea of ,trustees' as they are entrusted with power and have freedom to act autonomously on behalf of the principal. See Alter, supra note 122 , at 38-44.
} 
manifest in different ways. ${ }^{130}$ Importantly, if the power to recruit judges belongs predominantly to the judges themselves, the inherent information asymmetry between them, political branches and the general public, may easily give rise to particularistic interests.

Although it is selectors who shape the process the most, their choices are bound by the pool of candidates from which they are choosing future judges. To reasonably identify who is actually interested in judicial positions, researchers could greatly benefit from high levels of transparency that would allow them to learn about their characteristics in order to properly analyze them. ${ }^{131}$ In addition, to understand who even gets to the pool of candidates, it is important to pay attention to motivations of prospective judges to seek a judicial position. Building on Posner, ${ }^{132}$ I believe that in order for an individual to seek a judicial position, the utility of being a judge must outweigh the utility of working in another legal profession, and they must understand the costs of participating in the recruitment process as being reasonable and subjectively bearable, while also perceiving a reasonable chance to succeed in the process.

As for the utility of being a judge, candidates consider expected time devoted to judging, and time devoted to other activities. The reasonable balance between the two, which the work in the judiciary seems to offer, is particularly important to female judges who prefer to have enough time for their families more often than men. ${ }^{133}$ Reputation and income stemming from the judicial position may be among other factors determining one's willingness to become a judge. Indeed, perceived and expected enjoyment of a particular

\footnotetext{
${ }^{130}$ E.g. J. Mark Ramseyer \& Eric B. Rasmusen, Judicial Independence in a Civil Law Regime: The Evidence from Japan in 13 THE JOURNAL OF LAW, ECONOMICS AND ORGANIZATION 259 (1997); Ramseyer \& Rasmusen, supra note 22; David M. O'Brien \& Yasuo Ohkoshi, Stifling Judicial Independence from Within: , in JUDICIAL INDEPENDENCE IN THE AGE OF DeMocracy 37 (Peter H. Russell \& David M. O’Brien eds., 2001); Bobek \& Kosař, supra note 16; Kosař, supra note 13; Bogdan lancu, Perils of Sloganised Constitutional Concepts. Notably that of 'Judicial Independence', 13 EUROPEAN CONSTITUTIONAL L.R. 582 (2017); Coman \& Dallara, supra note 57; Lukasz Bojarski \& Werner Stemker Köster, The Slovak judiciary: its current state and challenges (Open Society Foundation 2012); Maria Popova, Be Careful What You Wish For: A Cautionary Tale of Post-Communist Judicial Empowerment, 18 DEMOKRATIZATSIYA 56 (2010); Maria Popova, Why Doesn't the Bulgarian Judiciary Prosecute Corruption?, 59 PROBLEMS OF POSTCOMMUNISM 35 (2012); Lydia F. Müller, Judicial Administration in Eastern Countries, in JUDICIAL INDEPENDENCE IN TRANSITION 937 (Anja Seibert-Fohr ed., 2012).

131 Several authors studied judicial selection using statistical analyses, e.g.: Vidal \& Leaver, supra note 121; Hanretty, supra note 98; Spáč, supra note 85. Another possibility is employing network analytcal approach, for an overview see Björn Dressel, Raul Sanchez-Urribarri \& Alexander Stroh, The Informal Dimension of Judicial Politics, 13 ANNUAL ReVIEW of LAW AND SOCIAL SCIENCE 413 (2017).

132 Richard A. Posner, What Do Judges and Justices Maximize? (The Same Thing Everybody Else Does), 3 SUPREME COURT ECONOMIC REVIEW 1, 31-39(1993).

${ }^{133}$ E.g. Duarte et al., supra note 72; or Matej Uhlík \& Samuel Spáč, Príčiny a dôsledky nadreprezentácie žien v slovenskom súdnictve, in NEDOTKNUTEL'Ní? POLITIKA SUDCOVSKÝCH KARIÉR NA SLOVENSKU V ROKOCH 1993-2015 (Erik Láštic \& Samuel Spáč eds., 2017).
} 
job would probably be a part of the consideration of any prospective candidate, as well as, for instance a feeling of personal contribution to the well-being of society or even the idea of 'justice.' Although, candidates may not only by motivated by virtue, but also can seek fulfilment of their personal interests, such as being able to exert influence in particular cases or even benefiting from participation in a system of corruption. ${ }^{134}$ As regards the costs of participation in the recruitment process, prospective judges may consider the time and energy necessary to ensure a reasonable chance for success in the process. For instance, if in Spain it is known that preparation for entry exams takes couple of years and is extremely demanding, it can easily discourage large number of potential candidates. Similarly, if prospective judges in Slovakia know that to succeed they need connections in the judicial system, it may prevent them from even seeking active consideration. Last but not least, as Alemanno warns with regard to CJEU and ECtHR, the transparency of the process may pose a threat to the integrity of candidates who might be subject to public scrutiny and can actually hurt their reputation. ${ }^{135}$

All in all, the recruitment process is not a perfect competition where only the best fit for the office succeed. It is rather a consequence of the interplay between motivations and interests of selectors and potential candidates for the judicial office in the context of a particular institutional design. Recruitment process translates into the composition of the bench, which in turn affects how the judiciary is performing. Taking these motivations into consideration hence may be in fact as important for the study of the judicial recruitment and its effects on the actual performance of the judiciary as is identifying crucial gatekeepers and critical junctions shaping the process.

\section{E. Conclusion}

The rise of judicial self-governance is clearly visible when it comes to the recruitment of new judges in Europe. This can be stated with confidence, not only with regard to the countries analyzed in this paper, but even in cases that were omitted here. ${ }^{136}$ Transferring these powers into the hands of judges seems to be a cure for a variety of diseases. In Ireland, a greater involvement of judges in judicial recruitment was a response to a political

\footnotetext{
${ }^{134}$ E.g. Daniel J. Beers, Understanding Corruption in the Post-Communist Courts: Attitudinal Data from Romania and Czech Republic ( $11^{\text {th }}$ Annual International Researchers Conference "Post-Communist Corruption: Causes, Manifestations, Consequences 2012).

${ }^{135}$ Alberto Alemanno, How Transparent is Transparent Enough? Balancing Access to Information Against Privacy

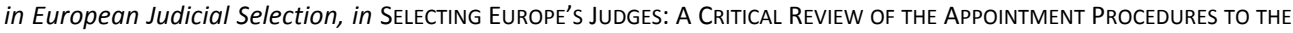
EUROPEAN COURTS 202 (Michal Bobek ed., 2015).

${ }^{136}$ See contributions on different jurisdictions in this issue, particularly Germany. Although it is rarely considered an example of strong judicial self-governance, even there judges play a substantive role in the recruitment of their colleagues: see Wittreck, supra note 51.
} 
crisis. ${ }^{137}$ In Slovakia, such a change occurred due to the unsatisfactory performance of the old model much similar to that found currently in Czechia. ${ }^{138}$ In the UK, the transfer of power was a consequence of a genuine desire for a better model supported by concerns for legitimacy, ${ }^{139}$ and in Romania it was a part of larger reforms towards greater judicial self-governance. ${ }^{140}$ Either way, judges seem to have more power than ever in recruiting their colleagues and successors.

International documents have called for the greater involvement of judges as a tool for ensuring recruitment based on merit, which is intended to result in candidates' increased capacity to properly perform their judicial functions. Nonetheless, this plan seems to have several shortcomings. First and foremost, there is no unified conception of what it is to be a good judge, or what makes one judge better than another, and hence it is practically impossible to evaluate whether a merit-oriented process delivers what it promises. ${ }^{141}$ Even if we allow that a judicial recruitment process controlled by judges delivers the best possible judges, there are many examples that undermine this assumption. As was discussed in the paper, merit-oriented processes tend to favor specific identity groups at the expense of others, as happens in France, ${ }^{142}$ the Netherlands ${ }^{143}$ and the UK, ${ }^{144}$ or they can be skewed towards candidates with stronger connections to the judiciary, as was the case in Slovakia. ${ }^{145}$ These examples suggest that no matter how the process of judicial recruitment is designed, it is shaped by the actors involved in it, and the outcome - the selection and appointment of judges - reflects their preferences, whether they are virtuous or driven by self-interest.

This is why there is a need for deeper study of how judicial recruitment models affect the composition of the bench. As was stated throughout the paper, judges play an indisputable role throughout the European systems of judicial recruitment. Although attention is usually paid to the formal rules and bodies, as well as the actors and institutions interacting in the process, other factors may be more significant for our deep understanding of the

\footnotetext{
${ }^{137}$ MacNeill, supra note 46 , at $38-47,88$.

${ }^{138}$ Spáč, supra note 85.

${ }^{139}$ E.g. Van Zyl Smit, supra note 1.

${ }^{140}$ E.g. Selejan-Gutan, supra note 62; or Parau, supra note 13.

${ }^{141}$ Dimino, supra note 6, at 819. For different approaches to the quality of judges see also: JASON E. WHITEHEAD, JUDGING THE JUDGES: VALUES AND THE RULE OF LAW (2014).

${ }^{142}$ Provine \& Garapon, supra note 73.

${ }^{143}$ De Lange, supra note 82 , at 243.

${ }^{144}$ E.g. Malleson, supra note 1; or Malleson, supra note 7.

${ }^{145}$ Spáč, supra note 85.
} 
recruitment of judges. In the paper, I proposed five stages in which candidates for judicial office may be eliminated until one or a few remain and are eventually appointed. Potential candidates must first and foremost be willing to bear the costs of the ambition to become a judge, which at times involves intensive preparation, as it does in Spain, where years of study are required, as well as possibly useful connections in the judicial system. ${ }^{146}$ Then $^{2}$ candidates need to meet the eligibility criteria for the position, get on the selector's radar to be actively considered, pass the selector's requirements to get on the shortlist, and eventually be selected and appointed. What matters more than whether judges play a role in the process, or through which body, is how other powers utilize their checks and balances and in which stages of the process. Arguably, the Irish JAAB enjoys considerably less control over who becomes a judge than the Czech court presidents do, even though the formal powers belong to the Czech political elites. Similarly, political actors in the UK and in Slovakia do not seem to contradict decisions made by the bodies of judicial selfgovernance, while similarly empowered political actors in Poland and in Slovenia have successfully constrained the discretion of judicial bodies. All in all, scholarly attention should not only focus on whether judges are involved in judicial recruitment, but rather at what stage and with what interests, as well as on how their powers are balanced by other actors, and how it all translates into the composition and performance of different judicial systems.

${ }^{146}$ Poblet \& Casanovas, supra note 56, at 161. 